\title{
Lack of identification of Flaviviruses in oral and cloacal swabs from long- and short-distance migratory birds in Trentino-Alto Adige (North-eastern Italy)
}

Michela Grisenti ${ }^{1,2^{*}}$, Daniele Arnoldi ${ }^{1}$, Franco Rizzolli ${ }^{1}$, Mario Giacobini ${ }^{2}$, Luigi Bertolotti ${ }^{2}$ and Annapaola Rizzoli ${ }^{1}$

\begin{abstract}
Background: West Nile virus (WNV) and Usutu virus (USUV), both belonging to the genus Flavivirus, are emerging in Italy as important human and animal pathogens. Migratory birds are involved in the spread of Flaviviruses over long distances, particularly from Africa to Europe. Once introduced, these viruses can be further be dispersed by short-distance migratory and resident bird species. Thus far, there is still a considerable knowledge gap on the role played by different bird species in the ecology and transmission mechanisms of these viruses. The Region of Trentino-Alto Adige (north-eastern Italy) is located on the migratory route of many of the short- and long-distance migratory birds that cross the Alps, connecting northern Europe and western Asia with southern Europe and Africa. Until now, only a silent circulation of WNV and USUV within the territory of the Province of Trento has been confirmed by serological screening, whilst no cases of infected humans or animals have so far been reported. However, continuous spillover events of both viruses have been reported in neighbouring Regions. The aim of this study was to monitor the circulation of WNV and USUV in Trentino-Alto Adige, in order to detect if active virus shedding occurs in migratory birds captured during their seasonal movements and to evaluate the role that different bird species could play in the spreading of these viruses.

Methods: We carried out a biomolecular survey on oral and cloacal swabs collected from migratory birds during seasonal migrations. Birds belonging to 18 transaharian and 21 intrapaleartic species were examined during spring $(n=176)$ and autumn $(n=146)$, and were tested using a generic nested-PCR.
\end{abstract}

Results: All samples tested negative for Flaviviruses. The possible causes of unapparent shedding, along with ecological and epidemiological implications are discussed.

Conclusions: The lack of detection of active virus shedding in these bird species does not exclude the circulation of these viruses within the Trentino-Alto Adige region, as reported in previous studies. The possible ecological implications are discussed.

Keywords: Flavivirus, Migratory birds, Oral and cloacal swabs, Survey

\footnotetext{
* Correspondence: michela.grisenti@fmach.it

${ }^{1}$ Edmund Mach Foundation, via E. Mach 1, San Michele all'Adige, Trento, Italy

${ }^{2}$ Department of Veterinary Sciences, University of Torino, via L. Da Vinci 44,

Grugliasco, Torino, Italy
} 


\section{Background}

The genus Flavivirus, family Flaviviridae, contains more than 70 viruses subdivided into three groups, according to their route of transmission: 1) arthropod-borne, infecting a range of vertebrate hosts through mosquito or tick bites; 2) those spread by an unknown vector, presumed to be limited to infecting vertebrates only, or; 3 ) those spread by insects only, called 'insect-specific flaviviruses' or 'mosquitoes-only flaviviruses', because they replicate only in mosquito-derived cells. When considering their observed pathogenicity for humans, those with highest impact on human health in Europe belong to the first group, and include West Nile Virus (WNV), Usutu Virus (USUV), and Tick-borne Encephalitis Virus [1,2] and references therein.

WNV is a zoonotic agent that has been reported in Africa since the beginning of the $20^{\text {th }}$ century and has since then radiated into Europe, India, Asia, Australia and America. During the last decade, new strains with various pathogenic characteristics have been discovered [3-5]. WNV is maintained in nature by a cycle involving ornithophilic mosquitoes as the vector, principally Culex spp., and birds that are the amplifying hosts. It infects a broad range of avian and mammalian species, but has also been reported to infect reptiles and amphibians. Other mechanisms of transmission include mites and ticks, organ transplant, blood transfusion, breastfeeding, intrauterine infection, and the fecal-oral route [6-11] and references therein. In Italy, WNV lineage 1 has been circulating since 1998 [12]. Surveillance activities established in 15 Italian wetlands from 2001 to 2007 detected only sporadic WNV circulations in several areas through seroconversions in chickens and horses [13-15] and references therein. Since 2008, WNV lineage 1 has been detected in animals, mosquitoes, and humans in an increasing number of Italian Regions each year, with clinical symptoms reported in horses and humans [16]. In 2011, the first human infection of WNV lineage 2 was discovered in central Italy, and later detected in birds and mosquitoes in north-eastern Italy and Sardinia $[17,18]$. Based on phylogenetic analyses, isolated strains were grouped in eight distinct lineages [19]. WNV infection results in flu-like symptoms or neurological disorders with heavy sequelae and eventually death. Many studies, however, have shown that this virus can circulate silently, infecting animals and humans asymptomatically $[5,8,14,20,21]$.

USUV is another Flavivirus isolated for the first time from Culex neavei (Cx. neavei) mosquitoes in South Africa in 1959. It is maintained in nature by a mosquitobird transmission cycle, with the genus Culex as the main vector, and for several years it has been considered a virus with very low pathogenicity for humans and animals [22]. It was historically only detected in tropical and subtropical Africa. However, the first European cases were confirmed in Italy in 1996 [23] and then in Austria in 2001 [24], resulting in the deaths of several species of resident birds, including Blackbirds (Turdus merula), Great Gray Owls (Strix nebulosa) and Barn Swallows (Hirundo rustica) $[23,24]$. In the following years, the virus was detected in birds and/or mosquitoes of several countries, including more cases in Italy [14,25], Switzerland [26], the UK [27] and Germany [28]. Moreover, the virus appears to have increased in pathogenicity, with fatalities in European wild birds [23,26]. In 2009, the virus was linked to neurological disorders in humans for the first time in Italy [25] and references therein.

Wild birds are believed to have the potential to maintain, transport, and disperse several Flaviviruses, as reviewed by some authors e.g.: [29]. Wild birds living in Africa, Europe and Asia can be divided in migratory and non-migratory (or 'resident'). The latter permanently live in the territory where they are born and travel only short distances to search for food and new ecosystems. Migratory birds annually undertake journeys, principally in spring and autumn, from their reproductive territory to where they will spend the winter (overwintering grounds) and viceversa. The former include intrapaleartic (or short-distance) migrants moving between Europe, Asia and North Africa; whilst others are long-distance or transaharian migrants, flying between Europe and southern Africa. Since the first appearance of WNV in North America in 1999 [30], much research has been carried out to understand the epidemiological role of bird species, demonstrating that migratory birds are implicated in the spread of diseases over long distances, such as from Africa into Europe, while the successive spread at a local level is mainly induced by resident and short-distance migrants, both for WNV and USUV e.g.: [23,26,29,31] and references therein. At the stopover sites along their migratory route and once they reach their destination grounds, migratory birds share common habitats with resident species from which they are otherwise separated during the rest of the year, and this exposes them to a great range of vectors and pathogens. The physiological stress of migration can increase their susceptibility to WNV, and/or lead to the reactivation of latent and chronic infections [29,32,33] and references therein.

Among the non-vectorial transmission routes of WNV between birds, oral and fecal viral shedding plays a central epidemiological role for many reasons. The fecal-oral secretions and excretions can contaminate the environment, leading to a high number of individuals coming into contact with the virus. In addition, this transmission route can take place in several ways, such as direct and indirect contact (e.g.: inhalation of aerosols, ingestion of contaminated food, preening soiled feathers), intra- and interspecies socialization, feeding of the nestlings, cannibalism and scavenging of infected carcasses. In fact, the viremia in orally-infected animals is similar to the one reached 
after mosquito bites $[7,8,10,11,34]$ and references therein. Furthermore, oral and fecal shedding may last longer than the viraemic phase (usually less than 7 days [11]), can occur without apparent clinical signs, and may play an important role in determining whether WNV can become established in areas or during seasons when the mosquito densities are too low to provide significant vector-borne transmission [14]. Oral and fecal shedding and/or oral infection have also been reported in some species of mammals and reptiles [10] and references therein.

Very little is currently known about USUV, mainly because it was historically confined to Africa, and because its pathogenicity to humans and animals has only recently been recognised. Moreover, these studies have focused in detecting the virus in dead birds e.g.: [23,28], through serological tests e.g.: $[27,31]$ or through virological or biomolecular testing of blood samples [35]. Fewer studies using oral and cloacal swabs have been carried out to detect USUV [36,37], and only two studies to date have detected the virus [38,39], although in another study it was detected in gastrointestinal tract and kidneys of birds using a biomolecular test [40].

Trentino Alto-Adige, a mountainous Region in northerneastern Italy, is located on many of the short- and longdistance routes of migratory birds that, from northern Europe, cross the Alps on their way to western Asia or Africa and viceversa [41,42]. So far, only a silent circulation of WNV and USUV in this Region has been detected [14], but the animal species are involved in this cycle have not yet been determined. Despite WNV and USUV sharing some ecological characteristics, knowledge of the natural transmission cycle and of the importance of non-vectorial transmission of USUV are still lacking. Due to the strategic position of this Italian Region in relation to migratory flyways, and the possible role played by migratory birds in the introduction and dispersion of these two Flaviviruses, we carried out a biomolecular survey to detect if active virus shedding occurs in migratory birds captured during their seasonal migrations, and to evaluate the role of different species in spreading these viruses.

\section{Results}

A total of 43 birds were captured during the autumn of 2011, 176 during spring 2012, and 103 during autumn 2012 (Table 1). Among the 39 species captured, 18 were long-distance migratory, and 21 short-distance migratory species. Oral and cloacal swabs taken from each individual captured all tested negative for Flaviviruses. The positive control tested always positive, and the negative one resulted always negative.

\section{Discussion}

The transmission dynamics of Flaviviruses are based on a complex relationship among virus occurrence, host and vector species community composition, host behaviour, vector host preferences and competence, and environmental and climatic factors, making each spillover event a unique phenomenon resulting from the combination of all these factors [34] and references therein.

Since oro-fecal shedding is an important amplification route for these viruses, assessing the rate of oro-fecal shedding in various species is important to identify the amplification chain $[7,8,10,11,34]$ and references therein. Bird species differ in their susceptibility to WNV and USUV infection. For example, Passeriformes and Strigiformes are highly susceptible to USUV infection e.g.: $[23,26,28,35]$ and Passeriformes, Charadriiformes and Strigiformes are the principal host reservoirs and amplificators of $\mathrm{WNV}$, due to their long-lasting and high levels of viremia e.g.: [34,43,44]. Moreover, it has been suggested that a single species can act as a super-spreader of WNV [6].

In previous studies, the oro-fecal shedding of USUV was detected in domestic goose (Anser anser f. domestica [38]) and domestic chicken (Gallus domesticus [39]). Alternatively, 14 out of a total of 39 bird species analysed (for e.g.: Greenfinch Carduelis chloris, Great Tit Parus major, Pied Flycatcher Ficedula hypoleuca, Willow Warbler Phylloscopus trochilus, Icterine Warbler Hippolais icterina, Blackcap Sylvia atricapilla, Blackbird, European Robin Erithacus rubecula) previously tested negative in study also carried out in Italy [36]. Moreover, shedding was also not evident in the Eurasian Jay (Garrulus glandarius), domestic chicken, European Nightjar (Caprimulgus europaeus), European Bee-eater (Merops apiaster), Barn Swallow, Cetti's Warbler (Cettia cetti), Blue Tit (Parus ceruleus) [36], and for 11 species belonging to the order Anseriformes tested in Finland [37].

With respect to WNV, the species tested by [36], the 11 species belonging to the order Anseriformes, screened by [37], and the individuals belonging to the family Corvidae of British Colombia tested by [45] resulted negative for WNV shedding. In India, 119 species belonging to 30 families and in particular Cuculidae, Motacillidae, Silvidae, Turdidae (order Passeriformes) and Strigidae (order Strigiformes) were analysed and all tested negative [46]. This further corroborates the results of the current study. A study carried out in Spain did not find oral shedding in species belonging to several families, namely Threskiornithidae and Accipitridae [31]. The tracheal and cloacal swabs tested in Germany were negative [47]. The tested birds belonged to order Charadriiformes (e.g.: Ringed Plover Charadrius hiaticula, Little ringed Plover Charadrius dubius, Black-headed Gull Larus ridibundus), some to genus Calidris and Tringa, some to the orders Anseriformes (Anas spp.), Gruiformes (Water Rail Rallus aquaticus, Eurasian Coot Fulica atra) and Passeriformes, family Motacillidae (for e.g.: White Wagtail Motacilla alba, 
Table 1 Bird species tested in Trentino-Alto Adige in 2011 and 2012

\begin{tabular}{|c|c|c|c|c|c|c|c|c|}
\hline \multicolumn{2}{|l|}{ Bird species } & \multirow[t]{2}{*}{ Family } & \multirow[t]{2}{*}{ Order } & \multirow{2}{*}{$\begin{array}{l}\text { Migratory } \\
\text { pattern }^{\mathrm{a}}\end{array}$} & \multirow{2}{*}{$\begin{array}{c}2011 \\
\text { Autumn (n) }\end{array}$} & \multirow{2}{*}{$\begin{array}{c}2012 \\
\text { Spring (n) }\end{array}$} & \multirow{2}{*}{$\begin{array}{c}2012 \\
\text { Autumn (n) }\end{array}$} & \multirow[t]{2}{*}{ Tota } \\
\hline Scientific name & Common name & & & & & & & \\
\hline Otus scops & European scops owl & Strigidae & Strigiformes & L & - & - & 1 & 1 \\
\hline Cuculus canorus & Cuckoo & Cucilidae & Cuculiformes & L & - & 1 & - & 1 \\
\hline Jynx torquilla & Wryneck & Picidae & Piciformes & L & - & 1 & - & 1 \\
\hline Aegithalos caudatus & Long tailed tit & Egitalidae & Passeriformes & S & - & 2 & 2 & 4 \\
\hline Lanius collurio & Red backed shrike & Lanidae & Passeriformes & L & - & 5 & 1 & 6 \\
\hline Delichon urbica & House Martin & Irundinidae & Passeriformes & L & - & - & 5 & 5 \\
\hline Emberiza schoeniclus & Reed Bunting & Emberizidae & Passeriformes & S & - & 3 & - & 3 \\
\hline Prunella modularis & Dunnoch & Prunellidae & Passeriformes & S & 2 & 2 & - & 4 \\
\hline Anthus trivialis & Tree pipit & Moracillidae & Passeriformes & L & - & - & 1 & 1 \\
\hline Ficedula hypoleuca & Pied flycatcher & Muscicapidae & Passeriformes & S & - & 4 & 6 & 10 \\
\hline Muscicapa striata & Spotted flycatcher & Muscicapidae & Passeriformes & L & - & 12 & - & 12 \\
\hline Sylvia borin & Garden Warbler & Silvidae & Passeriformes & L & - & 9 & 1 & 10 \\
\hline Sylvia curruca & Lesser Whitethroat & Silvidae & Passeriformes & S & - & - & 3 & 3 \\
\hline Hippolais polyglotta & Melodius Warbler & Silvidae & Passeriformes & L & - & 2 & - & 2 \\
\hline Hippolais icterina & Icterin Warbler & Silvidae & Passeriformes & L & - & 2 & - & 2 \\
\hline Acrocephalus scirpaceus & Reed Warbler & Silvidae & Passeriformes & L & - & 15 & - & 15 \\
\hline Acrocephalus palustris & Marsh Warbler & Silvidae & Passeriformes & L & - & 5 & - & 5 \\
\hline Acrocephalus arundinaceus & Great reed Warbler & Silvidae & Passeriformes & L & - & 6 & - & 6 \\
\hline Sylvia atricapilla & Blackcap & Silvidae & Passeriformes & S & 1 & 23 & 1 & 25 \\
\hline Locustella naevia & Grashopper Warbler & Silvidae & Passeriformes & L & - & 1 & - & 1 \\
\hline Sylvia melanocephala & Sardinian Warbler & Silvidae & Passeriformes & S & - & 1 & - & 1 \\
\hline Philloscopus trochilus & Willow Warbler & Silvidae & Passeriformes & L & - & 10 & 5 & 15 \\
\hline Philloscopus collybita & Chiffchaff & Silvidae & Passeriformes & S & - & 9 & - & 9 \\
\hline Philloscopus sibilatrix & Wood Warbler & Silvidae & Passeriformes & L & - & 2 & - & 2 \\
\hline Periparus ater & Coal Tit & Paridae & Passeriformes & S & - & - & 7 & 7 \\
\hline Parus major & Graet Tit & Paridae & Passeriformes & S & - & 1 & - & 1 \\
\hline Phoenicurus phoenicurus & Redstart & Turdidae & Passeriformes & L & - & 2 & 2 & 4 \\
\hline Phoenicurus ochruros & Black Redstart & Turdidae & Passeriformes & S & - & - & 3 & 3 \\
\hline Oenanthe oenanthe & Wheatear & Turdidae & Passeriformes & S & - & - & 1 & 1 \\
\hline Turdus merula & Blackbird & Turdidae & Passeriformes & S & 6 & 6 & 15 & 27 \\
\hline Erithacus rubecula & Robin & Turdidae & Passeriformes & S & 9 & 33 & 24 & 66 \\
\hline Turdus viscivorus & Mistle Thrush & Turdidae & Passeriformes & S & 1 & - & - & 1 \\
\hline Turdus philomenos & Song Thrush & Turdidae & Passeriformes & S & 10 & 9 & 18 & 37 \\
\hline Turdus iliacus & Redwing & Turdidae & Passeriformes & S & - & - & 1 & 1 \\
\hline Luscinia megarhynchos & Rufus Nightingale & Turdidae & Passeriformes & L & - & 6 & - & 6 \\
\hline Fringilla coelebs & Chaffinch & Fringillidae & Passeriformes & S & 7 & 2 & 3 & 12 \\
\hline Coccothraustes coccothraustes & Hawfinch & Fringillidae & Passeriformes & S & 4 & 2 & - & 6 \\
\hline Carduelis spinus & Siskin & Fringillidae & Passeriformes & S & 1 & - & 3 & 4 \\
\hline Fringilla montifringilla & Brambling & Fringillidae & Passeriformes & S & 2 & - & - & 2 \\
\hline & Total (n) & & & & 43 & 176 & 103 & 322 \\
\hline
\end{tabular}

${ }^{\mathrm{a} E a c h}$ species was classified as intrapaleartic (S) and transaharian (L). 
Meadow Pipit Anthus pratensis) and others to the family Corvidae (Hooded Crow Corvus corone cornix).

On the other hand, additional studies have detected orofecal shedding of WNV in bird species of different families and orders. These include Corvidae, such as American Crows (Corvus brachyrhynchos), Fish Crows (Corvus ossifragus), Blue Jays (Cyanocitta cristata), Common Ravens (Corvus corax), Black-billed Magpies (Pica pica), Little Raven (Corvus mellori) for e.g.: [11,48-52]; Anatidae (order Anseriformes) such as Canada Goose (Branta canadensis), Wild Mallard (Anas platyrhynchos) and Domestic Goose [11,20,53]; Galliformes, such as Northern Bobwhite (Colinus virginianus), Turkey (Meleagridis gallopavo), domestic chicken, Red-legged Partridge (Alectoris rufa) $[11,54,55]$ and references therein; Gruiformes, such as American Coot (Fulica americana) [11]; Charadriiformes, such us: Killdeer (Charadrius vociferus), Ring-billed Gull (Larus delawarensis) [49]; Columbiformes, such as Mourning Dove (Zenaida macroura) and Rock Dove (Columba livia) [11]; Psittaciformes, such as Monk Parakeet (Myiopsitta monachus) and Budgerigar (Melopsittacus undulatus) [11]; Passeriformes, such as American Robin (Turdus migratorius), Common Grackle (Quiscalus quiscula), House Finch (Carpodacus mexicanus), House Sparrow (Passer domesticus), Great-tailed Grackles (Quiscalus mexicanus), Cedar Waxwing (Bombycilla cedrorum), Northern Mockingbird (Mimus polyglottus), Barn Swallow (Hirundo rustica), Cliff Swallow (Petrochelidon pyrrhonota) [49,56,57]; several species of diurnal and nocturnal raptors, such as Swainson's Hawk (Buteo swainsoni), Ferruginous Hawk (Buteo regalis), Peregrine Falcon (Falco peregrinus), Golden Eagle (Aquila chrysaetos), American Kestrel (Falco sparverius), and some species of North American owls (family Strigidae) like Great Horned Owl, (Bubo virginianus) $[11,49,58,59]$.

The results of our study further corroborate the results of a previous study also carried out in Italy, which found there was no evident oro-faecal shedding of USUV in the families Fringillidae, Lanidae, Paridae, Muscicapidae, Silvidae, Turdidae, Hirundinidae and Picidae [36]. Our results also seem to suggest that birds belonging to the families Motacillidae, Prunellidae, Emberizidae, Cuculidae, Egitalidae, Strigidae, previously never screened for USUV, may not be important shedders of this virus.

Considering the migratory birds tested in Italy so far, what has been said for USUV is also valid for WNV. Moreover, this has also been confirmed in India in birds belonging to the families Cuculidae, Motacillidae, Silvidae, Turdidae (order Passeriformes) and Strigidae (order Strigiformes) [46] and in Germany for Motacillidae [47]. Of the studies that found oro-fecal shedding for WNV, only one was carried out in Europe, but is not possible to compare it with our research mainly for two reasons: firstly, it studied a species belonging to the order
Galliformes that was not included in the current study; and secondly, the birds were experimentally infected with the virus, and so the results may not reflect those seen in natural conditions in the wild [54]. The other studies were carried out in America and Australia and principally focused on taxonomic groups that are different from the ones that were included in our research (orders: Columbiformes, Psittaciformes, Charadriiformes, Gruiformes, Galliformes, Anseriformes, Falconiformes). Studies that have been carried out on Strigiformes and Passeriformes, also investigated different species to the ones included in our study (for e.g.: family Corvidae, American Robin, Common Grackle, House Finch, House Sparrow, Cliff Swallow, Golden Eagle, Bubo spp., Buteo spp., Falco spp.).

Accordingly, it seems that the oro-fecal shedding of USUV and WNV in Cuculiformes and Piciformes is not intense or it lasts only few days. Regarding Strigiformes and Passeriformes, their shedding seems low also for USUV, but for WNV, various families or species could have an important role, such as Corvidae, Hirundinidae, Icteridae, Turdidae, Fringillidae, Passeridae, Bombycillidae, Mimidae and Tytonidae. There are several factors that could explain these different results, for example, the limited number of subjects that were tested and the taxonomical differences between the birds screened. Also, an additional reason could be the period of the year during which the study was carried out in relation to the bird's physiology: migration requires morphological and physiological changes [33] that could interfere with the viral replication. Moreover, the oro-fecal shedding generally lasts less than 10 days [11], thus being not easy to detect in clinically healthy animals as in those individuals who are migrating. Besides, the shedding is not always followed by virus transmission e.g.: $[10,54]$ and references therein.

Taking into account the need to identify the species and the timing of WNV and USUV amplification, the absence of active shedding detected in this study may also justify the absence of clinically reportable cases of spillovers events to human and animal in Trentino-Alto Adige. Furthermore, at present, no human or animal clinical case of diseases or infections caused by Flaviviruses have been recorded in this region of Italy. Their circulation is then apparently very limited, in contrast to the high number of cases and the pathogenicity observed in animals, mosquitoes and humans in the neighbouring regions (Veneto, Lombardy, Emilia-Romagna, Friuli-Venezia Giulia: Figure 1). A possible explanation of this observed epidemiological pattern could be due to the low density of mosquitoes observed in this area as a result of a low habitat suitability for Culex spp.: a combination of low anthropization and mountainous orography of the territory, of which about 78\% lies over 1,000 m above sea level, and about $55 \%$ is covered by coniferous and deciduous forests, with a temperate-oceanic climate, although a sub- 


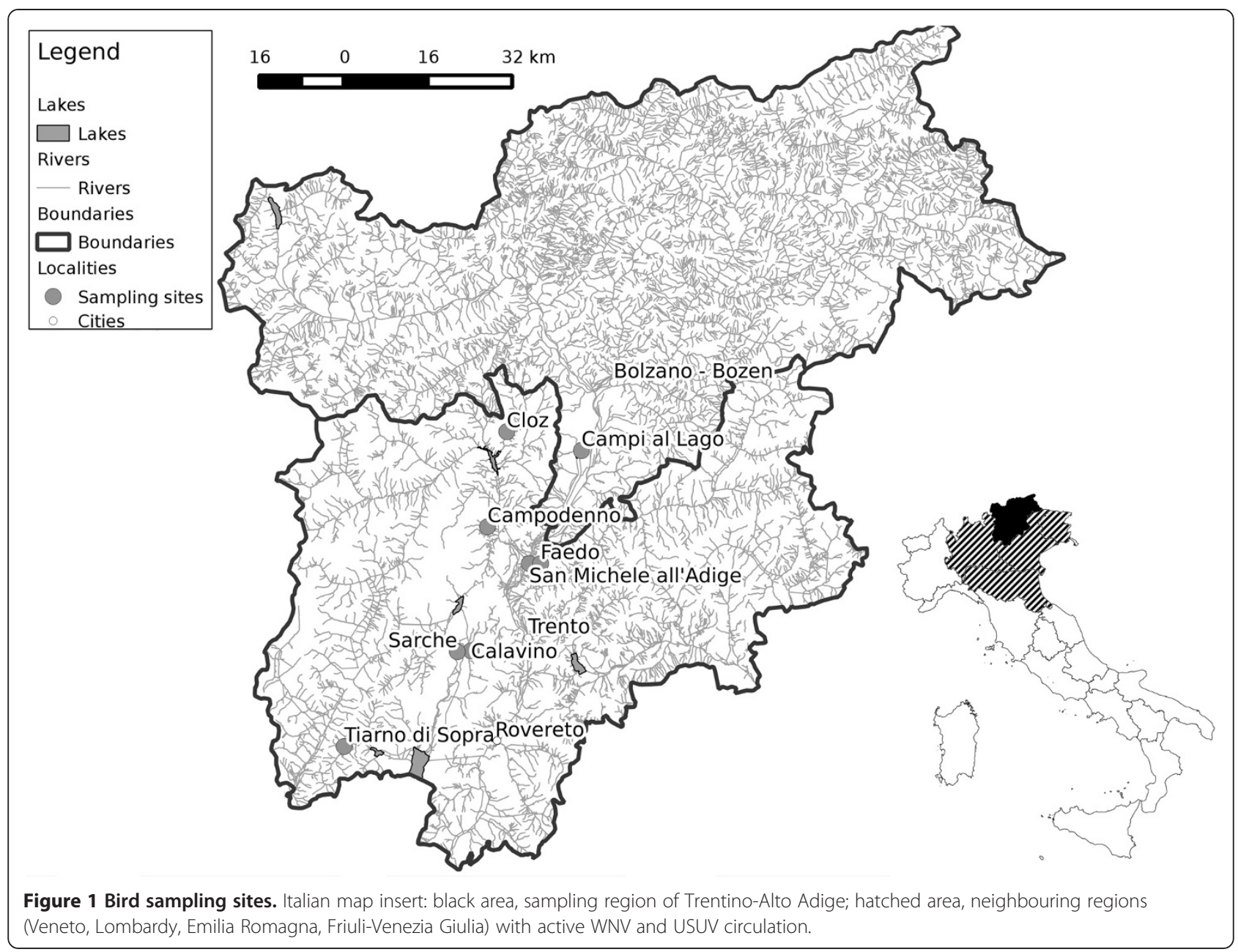

Mediteranean climate can be found near Lake Garda. It is not the case that most of the detections of Flaviviruses monitored in this region were obtained in the region around Lake Garda, which provides a suitable habitat for many species of mosquitoes, including $C x$. pipiens and Aedes albopictus [60,61], Rizzoli A: personal communication. This is consistent with the observation that viruses transmitted by mosquitoes are more frequently linked to mild climate, irrigated areas, wetlands and marshes with abundant mosquito and bird populations, especially migratory birds for e.g.: $[16,46,47,62]$. Another co-factor to be considered is the presence of a high avian biodiversity observed in the region compared to other neighbouring regions. The relationships among high host diversity and low virus spillover have been observed in several disease models, including WNV [6,63-65].

\section{Conclusions}

In this study we did not identify active oro-fecal shedding of WNV and USUV in 322 individual birds belonging to 18 transaharian and 21 intrapaleartic species. The lack of detection of active virus shedding in these species, however, does not exclude the circulation of these viruses within the Region of Trentino-Alto Adige, as noted in a previous study [14]. Considering the high rate of animals and goods movements into this territory, and possible future climatic changes, the temporal and spatial dynamics of pathogens, vectors and avian hosts could also change [66]; therefore, the circulation of Flaviviruses in Trentino Alto-Adige needs to be carefully monitored in the future.

\section{Methods}

\section{Bird netting}

Sample collection was carried out in Trentino-Alto Adige region during ringing campaigns in autumn 2011 and 2012 (September and October) and spring 2012 (March to May). Intrapaleartic and transaharian migratory birds were captured by ornithologists using net labyrinths authorized by ISPRA (Istituto Superiore per la Protezione e la Ricerca Ambientale, Ozzano dell'Emilia, Bologna, Italy) within the European Union for Bird Ringing (EURING) which includes ethical approval. The research protocol was also approved by the Wildlife 
Management Committee of the Autonomous Province of Trento (Italy). These activities are carried out to provide data on migration patterns, demography and ecological processes. The sampling sites included: Faedo (Trento) and Tiarno di Sopra (Trento) during the 2011 autumnal ringing campaing; Cloz (Trento), Campi al lago (Caldaro, Bolzano), Campodenno (Trento), Calavino (Trento) and Sarche (Trento) during the 2012 spring ringing campaing; Faedo (Trento), Tiarno di Sopra (Trento) and San Michele all'Adige (Trento) during the 2012 autumnal ringing campaing (Figure 1).

\section{Sampling}

Oral and cloacal samples were taken from each captured bird using sterile swabs with transport medium AMIES without charcoal, in polypropylene tubes $\varnothing 12 \times 150 \mathrm{~mm}$ (Nuova Aptaca S.r.l., Canelli - AT, Italy). Samples were kept refrigerated during transport to the laboratory, where they were stored at $-80^{\circ} \mathrm{C}$ until analysis. Each bird was manipulated only for few minutes and prior to its release, each one was marked by standard procedures using metal leg rings, according to EURING procedures. Date of capture, species, ring number, age, weight and other morphobiometric parameters were recorded for each individual.

\section{RNA extraction and Polymerase Chain Reactions (PCRs)}

Molecular analyses were performed in the laboratory of Veterinary Sciences Department of University of Torino (Grugliasco, Torino - Italy). For RNA extraction, each swab was dissolved in $200 \mu \mathrm{l}$ of phosphate-buffered saline (PBS) buffer (Sigma-Aldrich, Milan, Italy) and the suspension obtained was centrifuged for 5 minute at $8000 \mathrm{rpm} .140 \mu \mathrm{l}$ of the supernatant was added to $560 \mu \mathrm{l}$ of Buffer AVL and carrier RNA, prepared according to QIAamp ${ }^{\circ}$ Viral RNA Mini Handbook (Qiagen, Hilden, Germany). The samples were then processed following this protocol. In the final step, RNA was eluted in $60 \mu \mathrm{l}$ of Buffer AVE. After quantification with Thermo Scientific Nanodrop 2000 (Thermo-Scientific, Euroclone, Milan, Italy), up to $1 \mu \mathrm{g}$ of RNA was reverse-transcribed according to QiagenQuantiTect ${ }^{\circ}$ Reverse Transcription Kit Handbook (Qiagen, Hilden, Germany). For the screening of Flaviviruses, we used a generic nested RTPCR that amplifies a region of the NS5 gene that is wellconserved within this genus, according to [67], with modifications (using a volume of $5 \mu \mathrm{l}$ of the cDNA of the first PCR, $5 \mathrm{U}$ of HotStarTaq DNA Polymerase (Qiagen, Hilden, Germany), 40 pmol of each generic Flavivirus primer (Flavi1+, Flavi1-), and $10 \mathrm{nmol}$ of each dNTP). In the nested PCR mix, $1 \mu \mathrm{l}$ of PCR product from the first reaction was added to $49 \mu \mathrm{l}$ of reaction mix composed by $1.25 \mathrm{U}$ of HotStarTaq DNA Polymerase, 40 pmol of each primer (Flavi2+, Flavi2-), and
$10 \mathrm{nmol}$ for each dNTP. Finally, the products of the nested PCR were analysed by electrophoresis with a $1.5 \%(\mathrm{w} / \mathrm{v} \%)$ agarose gel (Sigma-Aldrich, Milan, Italy) and visualized by staining with $0.1 \%(\mathrm{w} / \mathrm{v} \%)$ of ethidium bromide. Positive and negative controls were included in the analyses.

\section{Abbreviations}

EURING: European Union for Bird Ringing; ISPRA: Istituto Superiore per la Protezione e la Ricerca Ambientale; PBS-buffer: Phosphate-buffered saline; PCRs: Polymerase chain reactions; USUV: Usutu virus; WNV: West Nile virus.

\section{Competing interests}

The authors declare that they have no competing interests.

\section{Authors' contributions}

MG and AR conceived and directed the study. MG, DA and FR carried out the bird netting and swabs collection. MG carried out the molecular analysis and drafted the manuscript. LB participated in the molecular analysis. MaG was involved in the interpretation of the data. All authors participated in the revision of the manuscript and approve the submitted version. All authors read and approved the final manuscript.

\section{Acknowledgements}

The authors acknowledge the EURING ornithologists for the collaboration in the birds sampling, and in particular the Science Museum (MUSE), Trento, Michele Segata, Stefano Noselli and Francesca Rossi. This work was partially funded by the $7^{\text {th }}$ Framework Programme: European West Nile collaborative research project (Grant agreement n. 261391; http://www.eurowestnile.org), and partially funded by Istituto Zooprofilattico Sperimentale di Piemonte Liguria e Valle d'Aosta - Ricerca Corrente 2011.

Received: 27 June 2013 Accepted: 3 October 2013

Published: 11 October 2013

\section{References}

1. Ishikawa T, Konishi E: Flaviviruses. Uirusu 2011, 61(2):221-238.

2. Huhtamo E, Moureau G, Cook S, Julkunen O, Putkuri N, Kurkela S, Uzcategui NY, Harbach RE, Gould EA, Vapalahti O, Lamballerie X: Novel insect-specific flavivirus isolated from northern Europe. Virology 2012, 433:471-478.

3. Bakonyi $T$, Ivanics E, Erdélyi K, Ursu K, Ferenczi E, Weissenböck H, Nowotny $\mathrm{N}$ : Lineage 1 and 2 strains of encephalitic West Nile virus, central Europe. Emerg Infect Dis 2006, 12(4):618-623.

4. Pradier S, Lecollinet S, Leblond A: West Nile virus epidemiology and factors triggering change in its distribution in Europe. Rev Sci Tech 2012, 31(3):829-844.

5. Sambri V, Capobianchi M, Charrel R, Fyodorova M, Gaibani P, Gould E, Niedrig M, Papa A, Pierro A, Rossini G, Varani S, Vocale C, Landini MP: West Nile virus in Europe: emergence, epidemiology, diagnosis, treatment, and prevention. Clin Microbiol Infect 2013, 19(8):699-704.

6. Kilpatrick AM, Daszak P, Jones MJ, Marra PP, Kramer LD: Host heterogeneity dominates West Nile virus transmission. Proc Biol Sci 2006, 273:2327-2333.

7. Zeller HG, Schuffenecker I: West Nile Virus: an overview of its spread in Europe and the Mediterranean basin in contrast to its spread in the Americas. Eur J Clin Microbiol Infect Dis 2004, 23:147-156.

8. Monini M, Falcone E, Busani L, Romi R, Rugger FM: West Nile Virus: characteristics of an African virus adapting to the third millennium world. The Open Virol J 2010, 4:42-51.

9. Lawrie CH, Uzcátegui NY, Gould EA, Nuttall PA: Ixodid and Argasid Tick Species and West Nile Virus. Emerg Infect Dis 2004, 10(4):653-657.

10. Blázquez $A B$, Sáiz JC: West Nile virus (WNV) transmission routes in the murine model: intrauterine, by breastfeeding and after cannibal ingestion. Virus Res 2010, 151:240-243.

11. Komar N, Langevin S, Hinten S, Neneth N, Edwards E, Hettler D, Davis B, Bowen R, Bunning M: Experimental infection of North American birds with the New York strain of West Nile virus. Emerg Infect Dis 2003, 9:311-327.

12. Autorino GL, Battisti A, Deubel V, Ferrari G, Forletta R, Giovannini A, Lelli R, Murri S, Scicluna MT: West Nile virus epidemic in horses, Tuscany region, Italy. Emerg Infect Dis 2002, 8:1372-1378. 
13. Filipponi G, Lelli R, Savini G, Giovannini A, Guberti A, Santucci U, Romi R, Toma L, Goffredo M, Caporale V: West Nile Virus surveillance in Italy: results of three years activities. In National Conference on West Nile Virus in the United States, San Jose, California. Teramo, Italy: Istituto Zooprofilattico Sperimentale dell'Abruzzo e del Molise; 2005.

14. Rizzoli A, Rosà R, Rosso F, Buckley A, Gould E: West Nile virus circulation detected in northern Italy in sentinel chickens. Vector Borne Zoonotic Dis 2007, 7(3):411-417

15. Calistri P, Giovannini A, Savini G, Monaco F, Bonfanti L, Ceolin C, Terregino C, Tamba M, Cordioli P, Lelli R: West Nile Virus Transmission in 2008 in North-Eastern Italy. Zoonoses Public Health 2009, 57(3):211-219.

16. Monaco F, Savini G, Calistri P, Polci A, Pinoni C, Bruno R, Lelli R: West Nile disease epidemic in Italy: first evidence of overwintering in Western Europe? Res Vet Sci 2011, 91(2):321-326.

17. Bagnarelli P, Marinelli K, Trotta D, Monachetti A, Tavio M, Del Gobbo R, Capobianchi MR, Menzo S, Nicoletti L, Magurano F, Varaldo PE: Human case of autochthonous West Nile virus lineage 2 infection in Italy, September 2011. Euro Surveill 2011, 16(43):20002. http://www.eurosurveillance.org/ ViewArticle.aspx?Articleld $=20002$

18. IZSAM (Istituto Zooprofilattico Sperimentale di Abruzzo e Umbria): WNV Surveillance Bulletin; 2012. http://sorveglianza.izs.it/emergenze/west_nile/pdf/ Bollettino_riassuntivo_2012ENG_DEF.pdf.

19. Pesko KN, Ebel GD: West Nile virus population genetics and evolution. Infect Genet Evol 2012, 12:181-190.

20. Banet-Noach C, Simanov L, Malkinson M: Direct (non-vector) transmission of West Nile virus in geese. Avian Pathol 2003, 32:489-494.

21. Komar N, Panella NA, Boyce E: Exposure of domestic mammals to West Nile virus during an outbreak of human encephalitis, New York City, 1999. Emerg Infect Dis 2001, 7:736-738.

22. Nikolay B, Diallo M, Boye CS, Sall AA: Usutu virus in Africa. Vector Borne Zoonotic Dis 2011, 11(11):1417-1423.

23. Weissenböck H, Bakonyi T, Rossi G, Mani $P$, Nowotny N: Usutu virus, Italy, 1996. Emerg Infect Dis 2013, 19(2):274-277.

24. Weissenböck H, Kolodziejek J, Url A, Lussy H, Rebel-Bauder B, Nowotny N: Emergence of Usutu virus, an African mosquito-borne flavivirus of the Japanese encephalitis virus group, central Europe. Emerg Infect Dis 2002, 8(7):652-656.

25. Gaibani P, Pierro A, Alicino R, Rossini G, Cavrini F, Landini MP, Sambri V: Detection of Usutu-Virus-Specific IgG in Blood Donors from Northern Italy. Vector Borne Zoonotic Dis 2012, 12(5):431-433.

26. Steinmetz HW, Bakonyi T, Weissenböck H, Hatt JM, Eulenberger U, Robert N, Hoop R, Nowotny N: Emergence and establishment of Usutu virus infection in wild and captive avian species in and around Zurich, Switzerland-genomic and pathologic comparison to other central European outbreaks. Vet Microbiol 2011, 148(2-4):207-212.

27. Buckley A, Dawson A, Gould EA: Detection of seroconversion to West Nile virus. Usutu virus and Sindbis virus in UK sentinel chickens. Virol J 2006, 3:71.

28. Becker $N$, Jöst $H$, Ziegler $U$, Eiden $M$, Höper D, Emmerich P, Fichet-Calvet $E$, Ehichioya DU, Czajka C, Gabriel M, Hoffmann B, Beer M, Tenner-Racz K, Racz P, Günther S, Wink M, Bosch S, Konrad A, Pfeffer M, Groschup MH, SchmidtChanasit J: Epizootic emergence of Usutu virus in wild and captive birds in Germany. PLOS ONE 2012, 7(2):e32604. doi:10.1371/journal.pone.0032604.

29. Pfeffer M, Dobler G: Remergence of zoonotic arboviruses by animal trade and migration. Parasit Vectors 2010, 3:35. doi:10.1186/1756-3305-3-35.

30. Lanciotti RS, Roehrig JT, Deubel V, Smith J, Parker M, Steele K, Crise B, Volpe KE, Crabtree MB, Scherret JH, Hall RA, MacKenzie JS, Cropp CB, Panigrahy B, Ostlund E, Schmitt B, Malkinson M, Banet C, Weissman J, Komar N, Savage HM, Stone W, McNamara T, Gubler DJ: Origin of theWest Nile virus responsible for an outbreak of encephalitis in the northeastern United States. Science 1999, 286:2333-2337.

31. García-Bocanegra I, Busquets N, Napp S, Alba A, Zorrilla I, Villalba R, Arenas A: Serosurvey of West Nile virus and other flaviviruses of the Japanese encephalitis antigenic complex in birds from Andalusia, southern Spain. Vector Borne Zoonotic Dis 2011, 11(8):1107-1113.

32. Newton I: The Migration Ecology of Birds. 1st edition. Amsterdam: Academic Press/Elsevier; 2008.

33. Hedentröm A: Adaptations to migration in birds: behavioural strategies, morphology and scaling effects. Phil Trans R Soc B 2008, 363:287-299.

34. Reiter $P$ : West Nile virus in Europe: understanding the present to gauge the future. Euro Surveill 2010, 15(10):19508. http://www.eurosurveillance. org/NiewArticle.aspx?Articleld=19508.
35. Savini G, Monaco F, Terregino C, Di Gennaro A, Bano L, Pinoni C, De Nard R, Bonilauri P, Pecorari M, Di Gialleonardo L, Bonfanti L, Polci A, Calistri P, Lelli R: Usutu virus in Italy, an emergence or a silent infection? Vet Microbiol 2011, 151:264-274.

36. Lelli R, Savini G, Teodori L, Filipponi G, Di Gennaro A, Leone A, Di Gialleonardo $L$, Venturi L, Caporale V: Serological evidence of USUTU virus occurrence in northeastern Italy. Zoonoses Public Health 2008, 55(7):361-367.

37. Lindh E, Huovilainen A, Rätti O, Ek-Kommonen C, Sironen T, Huhtamo E, Pöysä H, Vaheri A, Vapalahti O: Orthomyxo-, paramyxo- and flavivirus infections in wild waterfowl in Finland. Virol J 2008, 5:35.

38. Chvala S, Bakonyi T, Hackl R, Hess M, Nowotny N, Weissenböck H: Limited pathogenicity of Usutu virus for the domestic chicken (Gallus domesticus). Avian Pathol 2005, 34:392-395.

39. Chvala S, Bakonyi T, Hackl R, Hess M, Nowotny N, Weissenböck H: Limited pathogenicity of Usutu virus for the domestic goose (Anser anser $f$. domestica) following experimental inoculation. J Vet Med B 2006, 53:171-175.

40. Weissenböck H, Kolodziejek J, Fragner K, Kuhn R, Pfeffer M, Nowotny N: Usutu virus activity in Austria, 2001-2002. Microbes Infect 2003, 5(12):1132-1136.

41. Spina F, Volponi S: Atlante della Migrazione degli Uccelli in Italia. 1. non-Passeriformi. Ministero dell'Ambiente e della Tutela del Territorio e del Mare, Istituto Superiore per la Protezione e la Ricerca Ambientale (ISPRA). Roma: Tipografia CSR; 2008.

42. Spina F, Volponi S: Atlante della Migrazione degli Uccelli in Italia. 2. Passeriformi. Ministero dell'Ambiente e della Tutela del Territorio e del Mare, Istituto Superiore per la Protezione e la Ricerca Ambientale (ISPRA). Roma: Tipografia SCR; 2008.

43. Semenov BF, Chunikhin SP, Karmysheva WY, Yakovleva NI: Studies of chronic arbovirus infections in birds. 1. Experiments with West Nile, Sindbis, Bhanja and SFS viruses. Vestn Akad Med Nauk SSSR 1973, 28(2):79-83.

44. Kramer LD, Bernard KA: West Nile virus infection in birds and mammals. Ann N Y Acad Sci 2001, 951:84-93.

45. Hayes EB, Komar N, Montgomery SP, O'Leary DR, Campbell GL: Epidemiology and transmission dynamics of West Nile Virus disease. Emerg Infect Dis 2005, 11:1167-1173.

46. Mishra N, Kalaiyarasu S, Nagarajan S, Rao MV, George A, Sridevi R, Behera SP, Dubey SC, McCracken T, Newman SH: Serological evidence of West Nile virus infection in wild migratory and resident water birds in Eastern and Northern India. Comp Immunol Microbiol Infect Dis 2012, 35(6):591-598.

47. Hlinak A, Mühle RU, Werner O, Globig A, Starick E, Schirrmeier H, Hoffmann $B$, Engelhardt A, Hübner D, Conraths FJ, Wallschläger D, Kruckenberg H, Müller T: A Virological Survey in Migrating Waders and Other Waterfowl in One of the Most Important Resting Sites of Germany. J Vet Med B 2006, 53:105-110.

48. Komar N, Lanciotti R, Bowen R, Langevin S, Bunning M: Detection of West Nile virus in oral and cloacal swabs collected from bird carcasses. Emerg Infect Dis 2002, 8:741-742.

49. Stone WB, Therrien JE, Benson R, Kramer L, Kauffman EB, Eldson M Campbell S: Assays to detect West Nile virus in dead birds. Emerg Infect Dis 2005, 11(11):1770-1173.

50. Kipp AM, Lehmann JA, Bowen RA, Fox PE, Stephens MR, Klenk K, Komar N, Bunning ML: West Nile Virus quantification in faeces of experimentally infected American and fish crows. Am J Trop Med Hyg 2006, 75:688-690.

51. Wheeler SS, Barker CM, Fang Y, Armijos MV, Carroll BD, Husted S, Johnson WO, Reisen WK: Differential impact of West Nile virus on california birds. Condor 2009, 111(1):1-20.

52. Bingham J, Lunt RA, Green DJ, Davies KR, Stevens V, Wong FY: Experimental studies of the role of the little raven (Corvus mellori) in surveillance for West Nile virus in Australia. Aust Vet J 2010, 88(6):204-210.

53. Swayne DE, Beck JR, Smith CS, Shieh WJ, Zaki SR: Fatal encephalitis and myocarditis in young domestic geese (Anser anser domesticus) caused by West Nile virus. Emerg Infect Dis 2001, 7(4):751-753.

54. Sotelo E: Gutierrez-Guzmán AV, Del Amo J, Llorente F, El-Harrak M, Pérez-Ramírez E, Blanco JM, Höfle U, Jiménez-Clavero MA: Pathogenicity of two recent Western Mediterranean West Nile virus isolates in a wild bird species indigenous to Southern Europe: the redlegged partridge. Vet Res 2011, 42(1):11. doi:10.1186/1297-9716-42-11.

55. Langevin SA, Bunning M, Davis B, Komar N: Experimental infection of chickens as candidate sentinels for West Nile virus. Emerg Infect Dis 2001, 7(4):726-729. 
56. Oesterle PT, Nemeth NM, VanDalen K, Sullivan H, Bentler KT, Young GR, McLean RG, Clark L, Smeraski C, Hall JS: Experimental infection of cliff swallows (Petrochelidon pyrrhonota) with varying doses of West Nile virus. Am J Trop Med Hyg 2009, 81(6):1159-1164.

57. Guerrero-Sánchez S, Cuevas-Romero S, Nemeth NM, Trujillo-Olivera MT, Worwa G, Dupuis A, Brault AC, Kramer LD, Komar N, Estrada-Franco JG: West Nile virus infection of birds, Mexico. Emerg Infect Dis 2011, 17(12):2245-2252.

58. Nemeth N, Kratz G, Edwards E, Scherpelz J, Bowen R, Komar N: Surveillance for West Nile virus in clinic-admitted raptors. Colorado. Emerg Infect Dis 2007, 13(2):305-307.

59. Gancz AY, Barker IK, Lindsay R, Dibernardo A, McKeever K, Hunter B: West Nile virus outbreak in North American owls, Ontario, 2002. Emerg Infect Dis 2004, 10(12):2135-2142.

60. Roiz D, Vázquez A, Sánchez-Seco MP, Tenorio A, Rizzoli A: Detection of novel insect flavivirus sequences integrated in Aedes albopictus (Diptera: Culicidae) in Northern Italy. Virol J 2009, 6:93.

61. Roiz D, Vázquez A, Rosso F, Arnoldi D, Girardi M, Cuevas L, Perez-Pastrana E, Sánchez-Seco MP, Tenorio A, Rizzoli A: Detection of a new insect flavivirus and isolation of Aedes flavivirus in Northern Italy. Parasit Vectors 2012, 5:223.

62. Calistri P, Giovannini A, Hubálek Z, lonescu A, Monaco F, Savini G, Lelli R: Epidemiology of west nile in europe and in the mediterranean basin. Open Virol J 2010, 4:29-37.

63. Keesing F, Belden LK, Dobson P, Harvell CD, Holt RD, Hudson P, Jolles A, Jones KE, Mitchell CE, Myers SS, Bogich T, Ostfeld RS: Impacts of biodiversity on the emergence and transmission of infectious diseases. Nature 2010, 468(7324):647-652.

64. Swaddle JP, Calos SE: Increased avian diversity is associated with lower incidence of human West Nile infection: observation of the dilution effect. PLOS ONE 2008, 3(6):e2488. doi:10.1371/journal.pone.0002488.

65. Ostfeld RS: Biodiversity loss and the rise of zoonotic pathogens. Clin Microbiol Infect 2009, 15(Suppl 1):40-43.

66. Fuller T, Bensch S, Müller I, Novembre J, Pérez-Tris J, Ricklefs RE, Smith TB, Waldenström J: The Ecology of Emerging Infectious Diseases in Migratory Birds: An Assessment of the Role of Climate Change and Priorities for Future Research. Ecohealth 2012, 9:80-88.

67. Sánchez-Seco MP, Rosario D, Domingo C, Hernandez L, Valdes K, Guzman M, Tenorio A: Generic RT-nested-PCR for detection of flaviviruses using degenerated primers and internal control followed by sequencing for specific identification. J Virol Methods 2005, 126:101-109.

\section{doi:10.1186/1743-422X-10-306}

Cite this article as: Grisenti et al:: Lack of identification of Flaviviruses in oral and cloacal swabs from long- and short-distance migratory birds in Trentino-Alto Adige (North-eastern Italy). Virology Journal 2013 10:306.

\section{Submit your next manuscript to BioMed Central and take full advantage of:}

- Convenient online submission

- Thorough peer review

- No space constraints or color figure charges

- Immediate publication on acceptance

- Inclusion in PubMed, CAS, Scopus and Google Scholar

- Research which is freely available for redistribution 